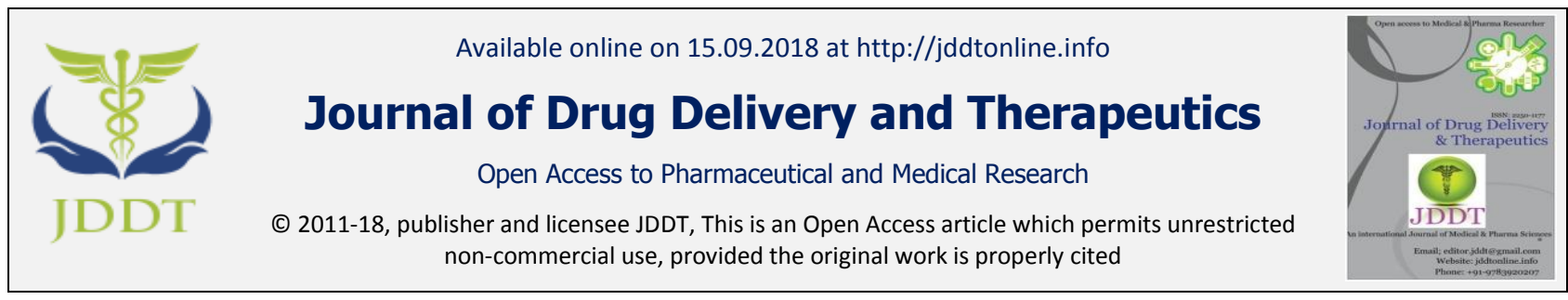

Open $\odot$ Access

Research Article

\title{
PHYTOCHEMICAL EVALUATION OF MONOCOT GRASS KYLLINGA TRICEPS ROTTB.
}

\author{
Amit Upadhyay *, Suman Jain, Neetu Bhalla, Kanika Arora \\ School of Studies, Pharmaceutical Sciences, Jiwaji University, Gwalior Madhya Pradesh, India
}

\begin{abstract}
Kyllinga triceps rottb. A monocot perennial herb found in various parts of India is traditionally used in vitiated conditions pitta and vata, hyperdipsia, fever, liver disorders, verminosis, cough, splenopathy, diabetes and dermatitis. The aim of the present study was to evaluate the phytochemical and pharmacognostical study of ignored ayurvedic medicinal herb kyllinga triceps rottb. The plant is monocot grass belongs to the family cyperaceae, commonly used in various ayurvedic preparation's and called musta. In various ayurvedic texts it is also known as nirvishi. Many species of family cyperaceae resembles the original drug thus the present study will help in identification and collection of original plant. The study includes identification and characterization of chemical component and preliminary phytochemical screening of the plant extract. The generated information of the present study will provide data which are helpful in the correct identification and authentication of medicinal plant kyllinga triceps rottb. and may help in prevention of its adulteration.
\end{abstract}

Keywords: Kyllinga triceps rottb., phytochemical, cyperaceae, adulteration, ayurevedic.

Article Info: Received 18 July, 2018; Review Completed 09 Sep 2018; Accepted 09 Sep 2018; Available online 15 Sep 2018

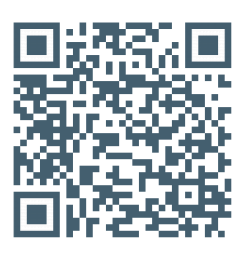

\section{Cite this article as:}

Upadhyay A, Jain S, Bhalla N, Arora K, phytochemical evaluation of monocot grass Kyllinga triceps rottb., Journal of Drug Delivery and Therapeutics. 2018; 8(5):204-208 DOI: http://dx.doi.org/10.22270/iddt.v8i5.1902

*Address for Correspondence:

Amit Upadhyay, School of Studies, Pharmaceutical Sciences, Jiwaji University, Gwalior Madhya Pradesh, India

\section{INTRODUCTION}

Herbal medicines are the use of plants and plant extracts as medicines. Standardization of natural products is a complex task due to their heterogeneous composition, which is in the form of whole plant, plant parts or extracts obtained thereof to ensure reproducible quality of herbal products, proper control of starting material is utmost essential. The first step towards ensuring quality of starting material is authentication. Thus, in recent years there has been a rapid increase in the standardization of selected medicinal plants of potential therapeutic significance. $1,2,3$

Plant is a major weed of improved pastures, but also occurs in crops, gardens, plantations and roadsides. It grows best in moist fertile soil that is seldom cultivated and in full sunshine. It is present in areas up to $7000 \mathrm{ft}$. elevation. The plant is naturalized primarily in gardens and lawns. The rhizomes of plant Kyllinga triceps rottb are fragrant, aromatic, sweet, astringent, bitter, refrigerant, febrifuge, antidiarrhoeal, diuretic, stomachic, anthelmintic, expectorant, demulcent and tonic. ${ }^{4-7}$ They are useful in vitiated conditions of pitta and vata, fever, cough, bronchitis, hepatopathy, splenopathy, diabetes, dermatitis, fistula and tumors ${ }^{7-11}$. The plant is used as an antidote in many parts of India. The root is a good refrigerant much used in fevers. Drug is also used in skin diseases and eye diseases Chinese call Kyllinga "shui wu gong" and uses it for common colds, bronchitis, malaria, arthritis and injuries ${ }^{12-13}$. Kyllinga is used for diarrhea in Malaysia and dysentery in china. Kyllinga is used in various places in Polynesia for joint pain and Rheumatic problems ${ }^{13-15}$. The spikes are applied as poultices from gathered nails. A decoction of the rhizome in used as diuretic, demulcent and tonic. It is given to relieve thirst in fevers and diabetes. Therefore, the objective of the present work is to 
evaluate various pharmacognostic and phytochemical properties of the plant.

\section{MATERIALS AND METHODS}

\section{Collection of specimen}

The species for the proposed study that is Kyllinga triceps rottb were collected from Bhoora Khon area of Shivpuri District of Gwalior Division (M.P.) with the help of Mr. N.K. Pandey (R.O.) National Research institute for ayurvedic-siddha (CCRAS) Amkho, Gwalior.

\section{Taxonomical Identification}

The species for the proposed study was identified as Kyllinga triceps by Dr. (Smt.) M.D. Gupta (Asst Director) and Mr. N.K. Pandey (R.O.) National Research Institute for Ayurveda and siddha (C.C.R.A.S.) under Ministry for Health and Family Welfare, Govt. of India, Amkho Gwalior (M.P.)

\section{Treatment}

First of all the rhizomes were washed with water and dried for one hour and then it was dried in shade. By the help of grinder the dried rhizome was powdered and was passed through the sieve no. 60 for powder analysis and coarse powder was used for phytochemical work.

\section{Preparation of plant extracts}

Preparation of the extract of Kyllinga triceps rottb, powdered rhizome is done by using ethanol and petroleum ether solvents. For both extracts cold percolation method was used for preparation of extracts of dried kyllinga triceps rottb, rhizomes powder, rhizome powder were extracted with $80 \%$ ethanol and petroleum ether separately for $24 \mathrm{hrs}$, which was filtered with 80 mesh nylon cloth. Raw material and solvent ratio was $1: 8$, total extraction procedure was repeated for five times, clean and sterile conditions were maintained throughout the extraction process so that there should be no chance of contamination. All the filtrates obtained after extraction were combined and again subjected for filtration with 250 mesh nylon cloth, finally extract was obtained was concentrated with reduced pressure ${ }^{16,17,18,19}$

\section{.Thin Layer Chromatography (TLC) ${ }^{18-21}$}

Thin layer chromatography is an important analysis tool in the separation, identification and estimation of different components. When a mixture of components is spotted on a TLC plate, the compounds which are readily soluble but not strongly adsorbed moves up along with the solvent and those not so soluble but strongly adsorbed move up less readily leading to separation of the compounds.

\section{Steps involved in TLC}

(a) Plate preparation

(b) Sample application as spots or bands over the chromatographic plate

(c) Solvent selection

(d) Adsorbent selection (e) Detecting agent

(f) Qualitative/Quantitative analysis

Silica gel $G$ was weighed in required quantity homogenous slurry was made with sufficient distilled water the slurry was poured on TLC glass plates by spreading technique and the uniform silica gel layer was adjusted to $0.25 \mathrm{~mm}$ thickness.

The coated plates were allowed for dry in air and activated by heating in hot air oven at $100-105^{\circ} \mathrm{C}$ for 1 hour and then used for TLC. The extracts were prepared with the respective solvent like ethanol and Petroleum ether and made up to $10 \mathrm{~m} 1$ in different test tubes.

Then with the help of capillary tube, extracts were spotted .on TLC plate, which was developed in TLC chamber, previously saturated with different solvent systems. By try and error, method, ethanol and Petroleum Ether extracts showed isolation and resolution of spots with following solvent systems, various solvent systems were developed according to fact that extract may contain terpenes and terpenoides, as main constituents which was previously suggested by literature survey and are already present in other species of cyperaceae.

\section{Column Chromatography}

Each compound in a mixture will have a particular solubility in the solvent and a particular tendency to be absorbed by the solid adsorbent, No two compounds mostly behave exactly, alike in these respects. This principle is utilized in column chromatography.

\section{Details of Column chromatography}

Adsorbent: Silica gel (for column chromatography 60120\#)

Fluent: Petroleum ether to water in gradation.

Length of Column: $60 \mathrm{~cm}$

Diameter of Column: $3.5 \mathrm{~cm}$

Amount of Ethanolic Extract used: $5 \mathrm{gm}$

Length of Column: $40 \mathrm{~cm}$ Packed

Rate of Elution: 30 drops per minute.

Fractions collected: Each of $100 \mathrm{ml}$

\section{Procedure}

First of all the column was filled with the sufficient silica gel 120 \# ) was filled up to $40 \mathrm{~cm}$ in the given column having height of $60 \mathrm{~cm}$ end $3.5 \mathrm{~cm}$ width. Then the column with cotton plug was carefully packed and uniformly filled with silica gel, by tapping the side of the column. Then the ethanolic extract of powdered Rhizome of Kyllinga triceps rottb was charged on column and eluted with solvents ranging from -nonpolar to polar at the rate of 30 drops per minute. Each fraction was collected in the volume of $100 \mathrm{ml}$ with different solvent ratio is given in table-8.

\section{Spectral data of isolated compound}

Compound isolated by reverse TLC of isolated fraction were subjected to Mass, ${ }^{1} \mathrm{HNMR},{ }^{13} \mathrm{CNMR}$ Spectral analysis for identification and structure establishment. 


\section{RESULT AND DISCUSSION}

Table 1: TLC of Ethanolic Extract and Petroleum Ether Extract of Powdered Rhizome of Kyllinga Triceps Rottb.

\begin{tabular}{|c|c|c|c|c|c|}
\hline S.No & Extract & Solvent System & No of Spots & Color of Spots & RF Value \\
\hline 1 & Ethanolic Extract & Chloroform Ethyl Acetate (60:40) & 3 & $\begin{array}{c}\text { Dark Blue } \\
\text { Greenish Blue } \\
\text { Black }\end{array}$ & 0.60 \\
& & & & 0.48 \\
0.40 & Dark Blue & 0.52 \\
2 & $\begin{array}{c}\text { Petroleum ether } \\
\text { extract }\end{array}$ & Ethyl Acetate: Hexane (30:70) & 3 & Greenish Blue & 0.45 \\
& & & Black & 0.50 \\
\hline
\end{tabular}

\section{Column Chromatography}

Table 2: Column Chromatography Of petroleum ether Extract of Powdered Rhizome of Kyllinga Triceps Rottb.

\begin{tabular}{|l|l|l|}
\hline No.of fraction. & Solvents & Colour of fractions \\
\hline F1-F2 & Hexane $(100)$ & Green \\
\hline F3-F10 & Hexane: Chloroform $(80: 20)$ & Light Green \\
\hline F1 1-F12 & Hexane: Chloroform(60:40) & Blackish green \\
\hline F13 -F14 & Hexane: Chloroform(40:60) & Dark green \\
\hline F15 - F16 & Hexane: Chloroform(20:80) & Green \\
\hline F17 - F18 & Chloroform $(100)$ & Greenish Blue \\
\hline F19 - F20 & Chloroform : Ethyl Acetate $(80: 20)$ & Blue \\
\hline F21- F22 & Chloroform : Ethyl Acetate $(60: 40)$ & Dark Blue \\
\hline F23 - F24 & Chloroform: Ethyl Acetate(40:60) & Dark Blue \\
\hline F25 - F26 & Chloroform: Ethyl Acetate(20:80) & Blackish Blue \\
\hline F27 - F28 & Ethyl Acetate $(100)$ & Brown \\
\hline F29 - F30 & Ethyl Acetate : Ethanol $(80: 20)$ & Yellowish Brown \\
\hline F31- F32 & Ethyl Acetate : Ethanol $(60: 40)$ & Reddish Brown \\
\hline F33 - F40 & Ethyl Acetate : Ethanol $(40: 60)$ & Green \\
\hline F41- F42 & Ethyl Acetate : Ethanol $(20: 80)$ & Brownish green \\
\hline F43 - F44 & Ethanol (100) & Red \\
\hline F45 - F46 & Ethanol: Water $(80: 20)$ & Dark Red \\
\hline F47 -F48 & Ethanol: Water $(60: 40)$ & Brown \\
\hline F49 - F50 & Ethanol: Water $(40: 60)$ & Reddish Brown \\
\hline F51-F52 & Ethanol: Water $(20: 80)$ & Brown \\
\hline F53-F54 & Water (100) & Light Brown \\
\hline
\end{tabular}

\section{TLC of Isolated Fractions}

Fraction $\mathrm{F}_{21}$ to $\mathrm{F}_{24}$ is considered as single fraction as reverse TLC of these fractions have given spots of same Rf values, which may be due to the presence of same compound.

Table 3: TLC of Isolated Fractions

\begin{tabular}{|c|c|c|c|c|}
\hline S1. No,. & Isolated Fractions & Solvents & Colour of Spot & RF Value \\
\hline 1 & F21 & chloroform Ethyl Acetate: $(60: 40)$ & Blue & 0.6 \\
\hline 2 & F22 & chloroform Ethyl Acetate: $(60: 40)$ & Blue & 0.61 \\
\hline 3 & F23 & chloroform Ethyl Acetate: $(40: 60)$ & Blue & 0.61 \\
\hline 4 & F24 & chloroform Ethyl Acetate: $(60: 40)$ & Blue & 0.61 \\
\hline
\end{tabular}

Spectral data of isolated compound

Compound: Colorless liquid

MS m/z (\%): 286, 271, 253, 187, 145, 117 and 91

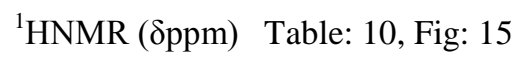

${ }^{13}$ CNMR (Sppm) Table: 11, Fig: 16 


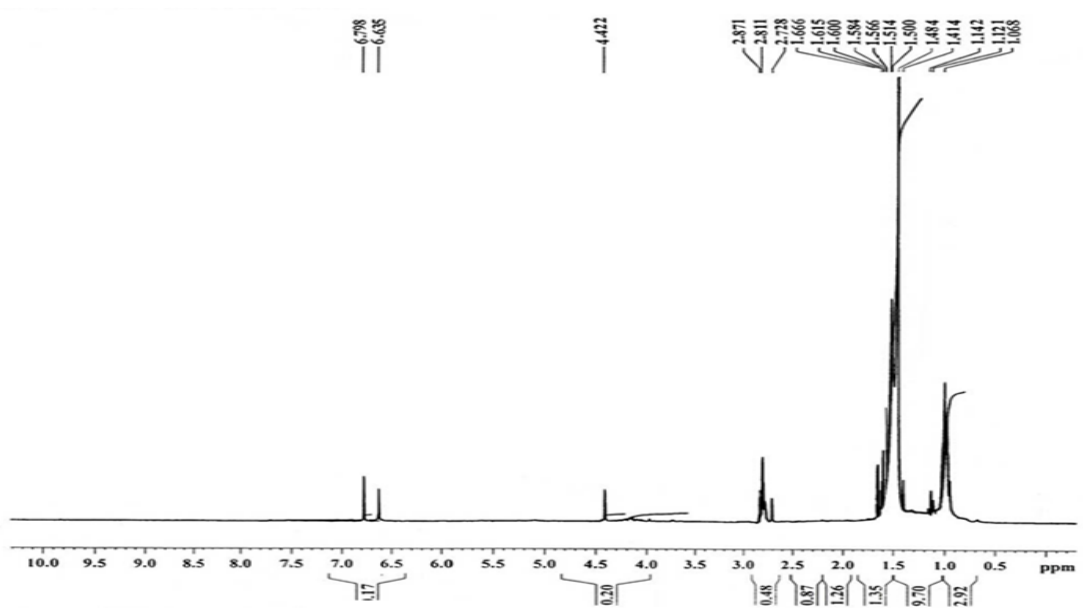

Figure 1: 1 HNMR spectra of isolated compound of Kyllinga triceps rottb petroleum ether extract

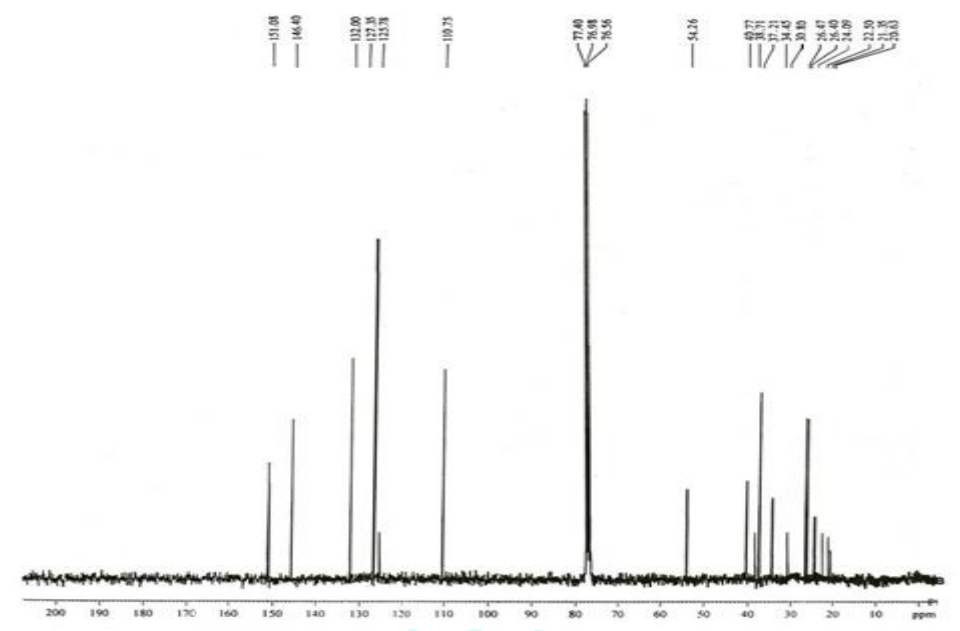

Figure 2: ${ }^{13} \mathrm{CNMR}$ spectra of isolated compound of Kyllinga triceps rottb Ethanolic extract

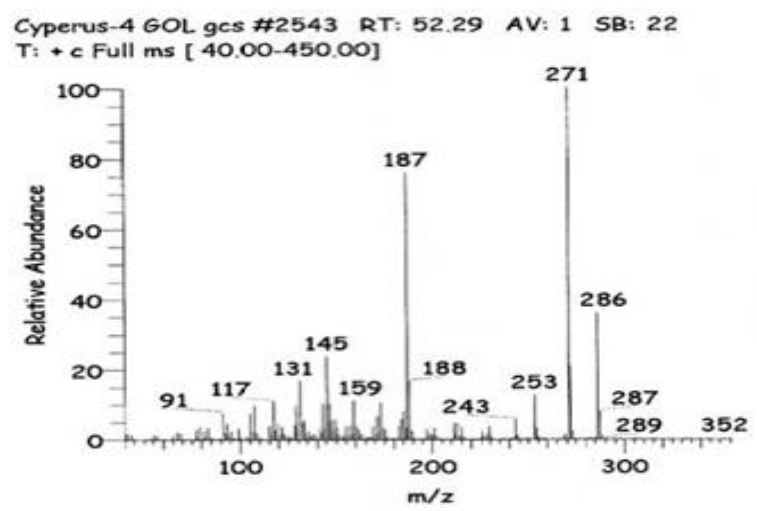

Figure 3: Mass spectra of isolated compound of Kyllinga triceps rottb petroleum ether extract

\section{Establishment of Structure of isolated Compound}

Constituent separated from petroleum ether extract of rhizomes of kyllinga triceps rottb. Has the molecular formula $\mathrm{C}_{20} \mathrm{H}_{30} \mathrm{O}$, was established by its mass spectrum data as its showed molecular ion-peak at $\mathrm{m} / \mathrm{z}(\%) 286$ (35) where the base peak is at 271. The fragment ion peaks are at 253(12), 187(78), 145(30), 117(14) and 91(9).

The ${ }^{1}$ HNMR spectral data confirm the structure of the compound the presence of phenolic $\mathrm{OH}$ which was observed at $\delta 4.62 \mathrm{ppm}$. The aromatic protons were reported at $\delta 6.79$ and $6.63 \mathrm{ppm}$. An angular methyl of trans configuration were recorded at $\delta 1.06 \mathrm{ppm}$. The geminal methyl of isopropyl moiety was observed at $\delta$ $1.12 \mathrm{ppm}$.

The structure was finally confirmed by its ${ }^{13} \mathrm{CNMR}$ spectra. A shift at $\delta 151.0 \mathrm{ppm}$ revealed the presence of a phenolic $\mathrm{OH}$ at $\mathrm{C}-13$. The aromatic carbons were found at $\delta 132.0,127.3,125.7$, and $110.7 \mathrm{ppm}$. The geminal dimethyl carbons of isopropyl moiety were at $\delta$ $22.5 \mathrm{ppm}$. 
The trans configuration of the compound was finally confirmed by the comparison of ${ }^{13} \mathrm{CNMR}$ data with its cis-isomers, where in the ring carbon C-3 and C-2 of cis-isomer were reported at $\delta 37.6$ and $50.1 \mathrm{ppm}$, which are more shielded than the ring carbons of trans-isomer, Present at $\delta 40.7$ and 54.2 ppm of carbons C-1 and C-2.

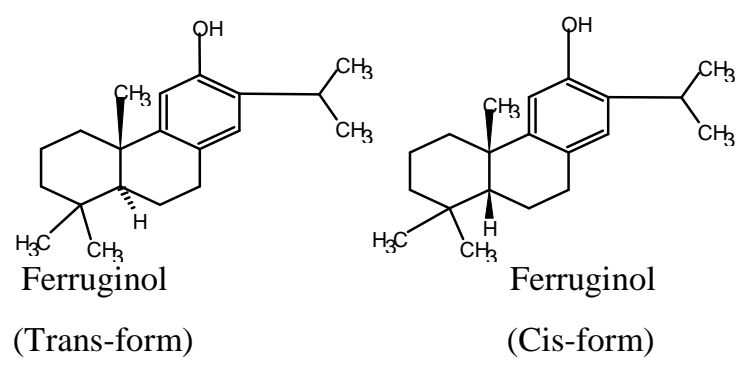

Figure 4: Structure of isolated compound of petroleum ether extract of Kyllinga triceps rottb.

Similarly two carbons being shared by the cyclohexane and aromatic moiety of both the isomers possess

\section{REFERENCES}

1. Reddy YSR, Venkatesh S, Ravichandran T, Subbaraju T, Suresh B. Pharmacognostical studies of Wrightia tinctoria bark. Pharma Biol. 1999; 37:291-295.

2. Venkatesh S, Madhava RB, Suresh B, Swamy MM, Ramesh M. Pharmacognostical identification of Rumex nepallensis Spreng (Polygonanceae)- an adulterant for Indian Rhubarb. Nat Prod Sci. 2004; 10:43-47.

3. Ahmad, M., Hussain, A., Wahab, S., Ansari, A., Singh, S., Mishra, C., \& Ahmad, S. Pharmacognostical and Phytochemical evaluation of root of Asparagus racemosus Willd. Journal of Drug Delivery and Therapeutics, 2017; 7(6):76-80. https://doi.org/10.22270/jddt.v7i6.1524

4. Verma N, Chaudhary A, Ahmed S, Garg VK, Analgesic and Anti Pyretic Potential Of Methanolic Extract of Kyllinga Triceps Rottb, International Journal of Pharma Professional's Research, 2016; 7(1):314-1318.

5. Shiddamallayya, N., Shantha T.R., Rama Rao V And Venkateshwarlu G.,Compearative Pharmacognosy of Cyperus Rotundus Linn and Kyllinga Bulosa P. Beauv., International Journal of Pharmaceutical Development \& Technology, 2015; 5(2):83-88.

6. Siddabathuni A, Dey A, Dey S, Evaluation of Anthelmintic Activity of Kyllinkga Triceps, International Journal of Pharmacy \& Life Sciences, 2014; 5(3):3385-3388.

7. Lal V.K., Gupta P.P., And Pandey Awanish, Hypoglycemic Effect of Kyllinga Triceps In Stz Induced Diabetic Rats, Diabetes \& Metabolism, 2012; 3(6):1000203-1000204.

8. Verma N, Jha K.K., Ahmad S, Garg VK, Assessment of Antidiabetic Potential of Kyllinga Triceps Rottb In Streptozotocin-Induced Diabetic Rats, Scientific Research \& Reviews, 2013; 1(1):8-11.

9. Aneela S, Dey A, Dey S, Gas Chromatography-Mass Spectrometry Analysis of Kyllinga Triceps,International Journal Pharmaceutical Sciences and Research, 2014; 5(7):2999-3003.

10. Vanapatla S Rani, Krishna M G., Ravi Kumar B., Effect of Root Extract Fractions of Kyllinga Triceps Rottb on Streptozotocin Induced Diabetic Rats, Stamford Journal of Pharmaceutical Sciences, 4(1):25-30. different values. The carbons of cis-isomers at C-7 and C-9 are found at $\delta 126.0$ and $145.3 \mathrm{ppm}$, whereas in trans-isomer they were found at $\delta 127.0$ and $146.4 \mathrm{ppm}$.

\section{CONCLUSION}

Phytochemical examination and characterization of medicinal plants have always been accorded due credentials in the pharmacognostical studies. Botanical identity of the plants is an essential prerequisite for undertaking the analysis of medicinal properties of any plant. A researcher may succeed in getting a new compound or may find many useful pharmacological active properties in the plant. If the botanical identity of the plant happens to be dubious or erratic, the entire work on the plant becomes invalid. Thus it is needless to stress the botanical identity of the crude drug is the threshold in the processes of pharmacological investigations. The researchers should be equipped with all possible diagnostic parameters of the plant on which the researchers plan to work. Present study may help in identification and future research on the plant kyllinga triceps rottb.
11. Gurjar H.P., Irchhaiya D.R., Vermas D.A. Review on some medicinal plants with antidiabetic activity. Journal of Drug Delivery and Therapeutics, 2016; 6(2):45-51.

https://doi.org/10.22270/jddt.v6i2.1199

12. Majumder $P$, Investigation of Anthelmintic Activity of An Ignored Plant 'Kyllinga Nemoralis' Tuber- A Potential Hope, International Journal of Pharma And Bio Sciences, 2013; 4(1):45-52.

13. Sindhu T, Rajamanikandan $S$, Srinivasan P., In Vitro Antioxidant And Antibacterial Activities of Methanol Extract of Kyllinga Nemoralis, International Journal of Pharmaceutical Sciences, March - April 2014; 170-174.

14. Rajagopal P.L., Sajith Kumar P.N., Sreejith K.R. , Premaletha K. , Phytochemical And Antioxidant Screening of the Aerial Parts of Kyllinga Nemoralis, International Journal of Science and Researchmethodology, August 2016; 4(2):6676.

15. HV Raju: Pharmacognostic Studies on Kyllinga monocephala. Indian Journal Natural Product 2007; 2:33-36.

16. Ghosh R., Deb P. A study on antioxidant properties of different bioactive compounds. Journal of Drug Delivery and Therapeutics, 2014; 4(2):105-115. https://doi.org/10.22270/jddt.v4i2.772

17. Wallis TE. Text book of Pharmacognosy, CBS Publisher and Distributors, 2001, 68-78.

18. Harborne JB, A guide to Modern Techniques of Plant Analysis, Chapman and Hall: London 1973, 39.

19. British Pharmacopoeia, Appendix XID A153 Vol. II HMSO: London, 1993

20. Mujahid, M. Phytochemical analysis and evaluation of scavenging activity of methanolic extract of adenanthera pavonina linn leaves. Journal of Drug Delivery and Therapeutics, 2015; 5(3):55-61. https://doi.org/10.22270/jddt.v5i3.1147

21. Paudel Prajwal, Satyal Prabodh, Khadka Ganesh And William N. Setzer, Leaf Essential Oil Composition of Kyllinga Brevifolia Rottb. From Nepal, Journal of Essential Oil Bearing Plants, Jeobp 2012; 15(5):854-857. 